\title{
都市内散水による気候緩和効果の現地観測 An Observation of the Climatic Effect of Watering on Paved Roads
}

\author{
木内 豪*, 神田 学**, 栗城 稔***, 小林 裕明**** \\ By Tsuyoshi KINOUCHI, Manabu KANDA, Minoru KURIKI and Hiroaki KOBAYASHI
}

\begin{abstract}
Growing cities have been deteriorating heat environment due to artiticial coverage of the ground and artificial heat eftluence. The authors focused on the watering on paved roads as one of effective and immediate measures against the situation and observed the effect on the micro climate in a city area in the last summer. The results showed that the difference in temperature and humidity at two points with and without watering were maximum 1.5 degree and $8 \%$, respectively. In addition, the estimated heat balance at the points showed that the considerable latent heat and the lateral heat transport contributed to lower the surface temperature of the road due to watering.

Key words: Watering, Paved roads, Micro climate, Heat balance, Thermal index
\end{abstract}

\section{1.はじめに}

近年、都市の気温が周辺地域よりも上昇するヒートアイランド現象が注目を集めている。気温の上昇はそこ で暮らしている人々にとって不快なものであり、冷房によるエネルギー消費が増大するという望ましくない状 況をもたらす。

都市の気候緩和のための即効性のある対策として地表面への散水が挙げられる。散水が熱収支に及ぼす影響 については実験と数値計算により明らかにする試みが行われている1)が、現地スケールで散水の気候緩和効果 を計測した事例はなく、現段階では実用上散水を行うための判断材料にそしい。そこで、筆者等は長岡市で消 雪パイプを利用した路面散水を行い、気温、湿度等を観測して、気候緩和策としての散水の有効性について検 討したのでここに報告する。

\section{2. 観測方法}

長岡市では冬季に効果的な除雪対策を行う ため、消雪パイプを道路中央に埋設し、降雪 時にある一定の積雪量に達すると地下水をポ ンプにより汲み上げ消雪パイプを通じて道路 面に散水を行っている。現地観測では、市内 に繸横に張り巡らされている消雪パイプのう ちの一部分（総延長約 $500 \mathrm{~m}$ ）を利用して道路 散水を行った。

観測は、1993年 8 月 13 日の午前 9 時から午

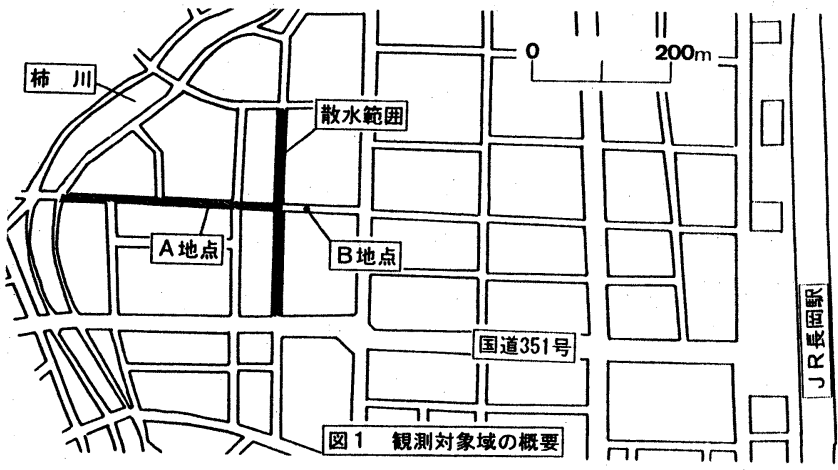
* 正会員 工修
** 正会員 工博
建設省土木研究所都市河川研究室（テ305 茨城県つくば市大字旭 1 番地）
*** 正会員 工修
山梨大学講師 土木環境工学科
（广400 山梨県甲府市武田 4-3-11）
**** 正会員
建設省土木研究所都市河川研究室 室長
建設省土木研究所都市河川研究室 
後 3 時までの間行った。なお、前日の夕方まで小雨が時折降る状態で観測当日も低温注意報が出されており、 午前中は快晴だったものの午後には再び曇り出すという不安定な天気であった。観測対象域を図-1に示す。観 測地点は散水区間内に 1 点、散水区間から約 $30 \mathrm{~m}$ 離れた地点に1点を設け、地上約 $1 \mathrm{~m}$ の高さに計測機器を設置 して地表面熱収支と気温、湿度、グローブ温度、風速、散水量等を計測した。また、自動車2台を利用して気 温と湿度の移動観測を試みた。散水は観測開始後1時間及び観測終了前1時間は行わず、午前10から午後 2 時ま での間のみ図中斜線で示した区間に散水を行った。計測機器の配置を表-1と図-2に示寸。表1以外にも、おお よその風向を記録し、また、1つの散水孔からの散水量と散水温を計測した。

表- 1 計測機器の配置

\begin{tabular}{|c|c|c|c|}
\hline$A, B$ 両地点 & 計測機器 & 精度等 & 記録間隔 \\
\hline 気温·湿度 & $\begin{array}{l}\text { 白金温度計 } \\
\text { 静電容量式 }\end{array}$ & $\begin{array}{l}\text { VAISALA製HMP130Y } \\
\pm 0.2^{\circ} \mathrm{C}, \pm 2 \% \mathrm{RH}\end{array}$ & $10 \mathrm{~s}$ \\
\hline$ク^{*}$ ロ-7゙温度 & 白金温度計 & 同上 & $10 \mathrm{~s}$ \\
\hline 風 & 三杯式風速計 & $-0.3 \mathrm{~m} / \mathrm{s}(3 \mathrm{~m} / \mathrm{s}$ 以下 $)$ & $10 \mathrm{~s}$ \\
\hline $\begin{array}{c}\text { 純放射・ } \\
\text { 下向き放射 }\end{array}$ & 放射收支計 & $\begin{array}{l}\text { EKO MF- } 11 \\
5 \%\end{array}$ & $\begin{array}{c}1 \mathrm{~s} \\
1 \text { 分平均 }\end{array}$ \\
\hline 地中伝導熱 & 熱 流 計 & EK0 MF-81 & 同上 \\
\hline 日 射 量 & 日射計 & 石川産業製, $\pm 1.5 \%$ & 同上 \\
\hline 地表面温度 & 放射温度計 & ミルW'IR-0510 $(\varepsilon=1)$ & 適時 \\
\hline A地点のみ & 計測機器 & 精度等 & 記録間隔 \\
\hline 風速·気温 & 超音波風速計 & $\pm 1 \mathrm{~cm} / \mathrm{s}, \pm 0.05^{\circ} \mathrm{C}$ & 2分平均 \\
\hline 散水温度 & 白金温度計 & $\pm 0.2^{\circ} \mathrm{C}$ & $10 \mathrm{~s}$ \\
\hline
\end{tabular}

\section{3. 観測結果}

\section{1 気温、湿度、風速}

図-3,4,5,6 樰地点の気温、湿度の計測結果と地 点間の気温差、湿度差の経時変化で、1 分間の平均 值を折れ線グラフで表している。観測当日は散水を 行ったA地点から散水なしのB 地点に向かう風が卓 越しており、散水域の影響が $\mathrm{B}$ 地点まで及んでいた と考えられる。それにもかかわらず午前10時から午 後 2 時までの散水時間帯では、平均的にみると、B 点の方が A点の気温を 0.5 度ほど上回り、日射量が 最も大きかった10:30〜11:30にかけては最高で約 1.5 度の違いが生じていた。一方、湿度に関しては、 散水時間帯内では平均して数\%ほどA地点の湿度が B地点を上回っており、最大で約 $8 \%$ の違いが見ら れた。観測開始後及び終了前 1 時間（散水を行わな かった時間）の観測結果によると両地点の温度、湿 度の差は平均的にはゼロか、むしろA地点で温度が 高く湿度が低いことから、散水時間帯の温度、湿度 の傾向は散水の効果によるところが非常に大きいと 言える。なお、両地点の風速は 1 分間の平均值でみ ると0〜 $3 \mathrm{~m} / \mathrm{s}$ 程度であった。

\section{2 体感温度 (グローブ温度)}

人間の温熱感覚は、気温、湿度とともに周囲の物

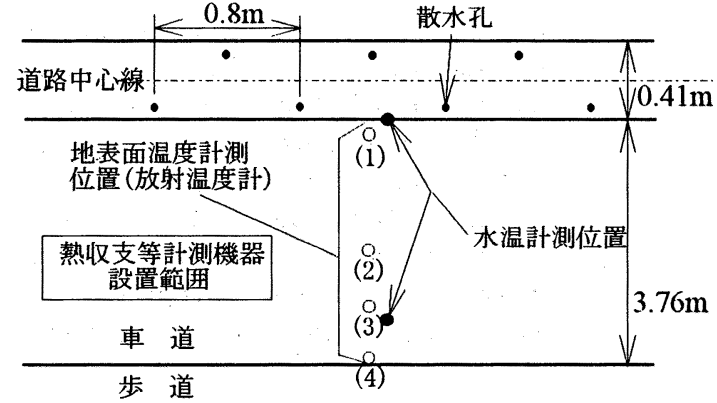

図-2 A地点の平面図

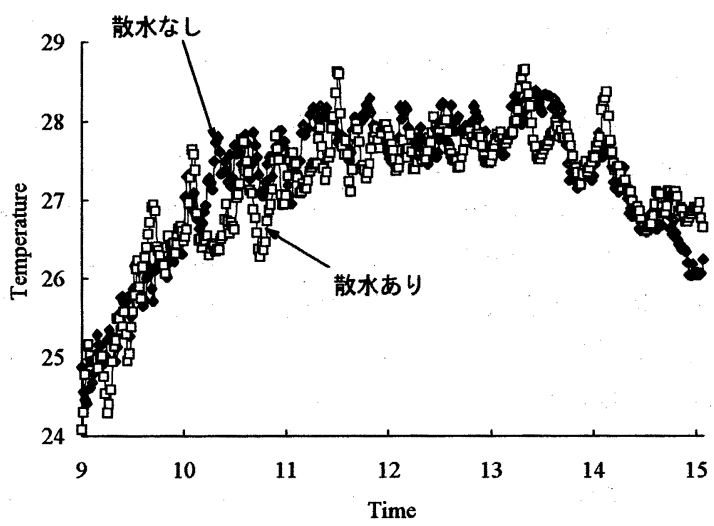

図-3 気温の時間変化

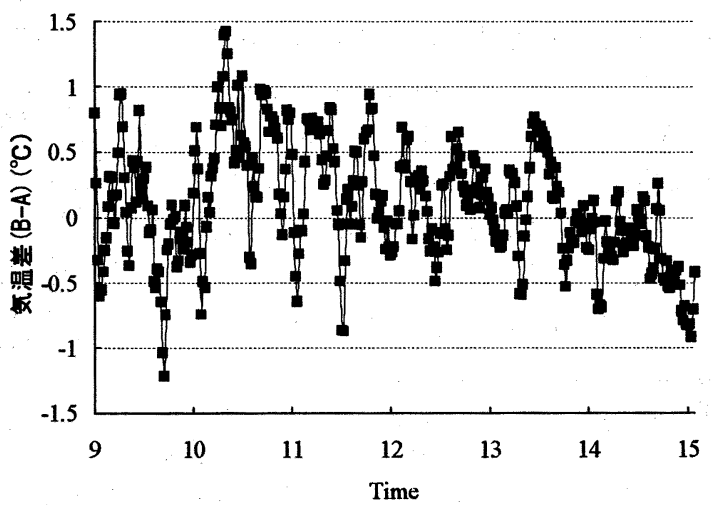

図-4 散水の有無による気温差 
体からの放射（輻射）や風に対しても反応するため、気温、湿度の条件が同じでも周囲の物体の有無や物体の 表面温度の違いに応じて体感温度が異なる。図-7,8は両地点でのグローブ温度及び温度差の時間変化を示した もので、散水時間帯での両地点の差は顕著で、日射が最大の時には約 4 度の温度差が生じていることがわかる。 A地点でグローブ温度が小さな值を示したのは温度計に最も近い位置にある道路の地表面温度が散水により低 く抑えられたことが大きく影響している。なお、両地点周辺の建物の状況は異なるものの、B地点の方が周囲 の建物が少なかった。

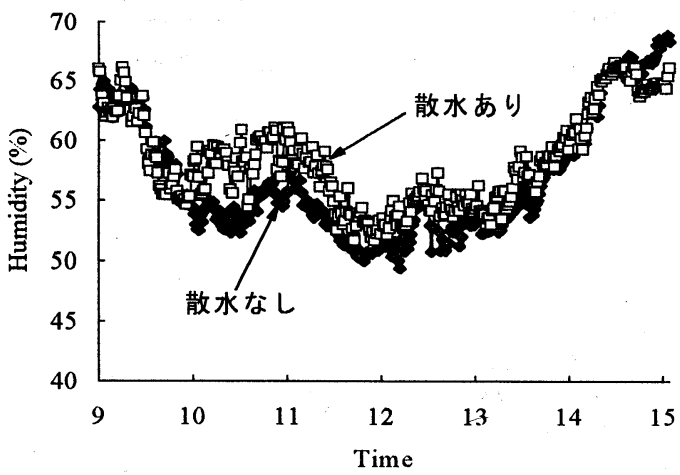

図-5 湿度の時閒変化

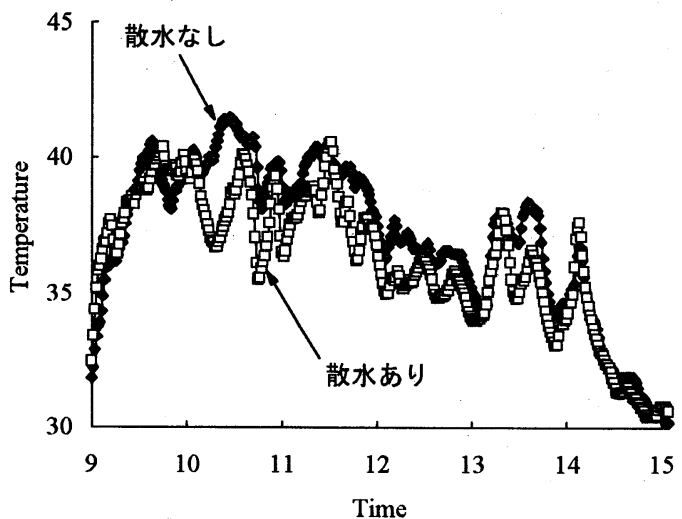

図-7 グローブ温度の時間変化

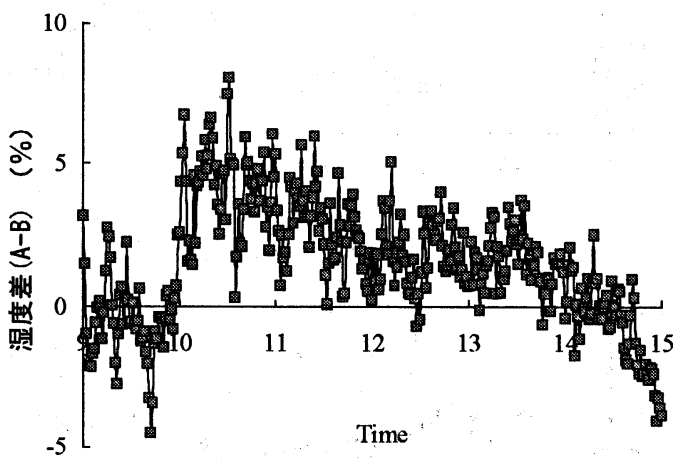

図-6＼cjkstart散水の有無による湿度差

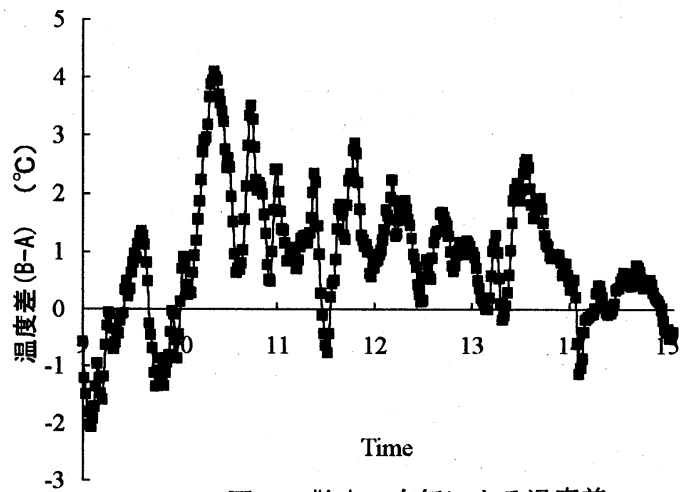

図-8 散水の有無による温度差

\section{3 放射量}

正味入射してくる熱量の計測結果について説明する。図-9は純放射量の経時変化を、図-10は両地点での上 向き日射量と下向き日射量の比(アルベド值)の経時変化を表している。散水の無い10時までは、A地点のアル ベドが若干大きく、この影響を受けて10時まではA地点での純放射量が B 地点を下回っているが、散水により 薄い水膜が形成されるためアルベドが約 $10 \%$ から約 $6 \%$ に減少していることがわかる。

\section{4 地表面温度}

A, B両地点における放射温度計を用いた地表面温度の計測結果を図-11に示す。A地点では散水孔のある道路 中央から歩道際までの間 4 地点で計測を行った（図-2）。この結果より、B地点では最高で50度に達したのに 対してA地点ではこれより10〜30度も低かったこと、路面の位置によって地表面温度が異なることがわかる。 熱収支式から算定される地表面温度と計測值を比較したものが図-12,13である。B地点では算定結果と計測值 がほぼ同様の值を示しているのに対してA地点では若干のずれが見受けられるが、この理由は熱収支の計測に 
より得られる值はある範囲の平均的な值であるのに対して、放射温度計による計測は限られた狭い範囲の值で あり、また、路面の濡れ具合にむらがあったためと考えられる。

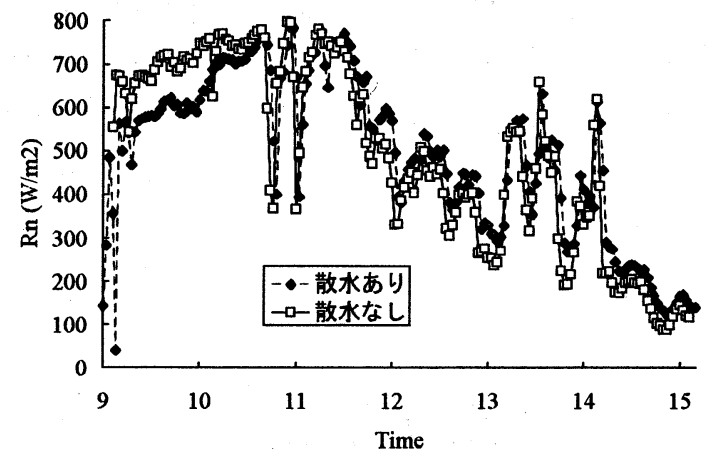

図-9 純放射量の時間変化

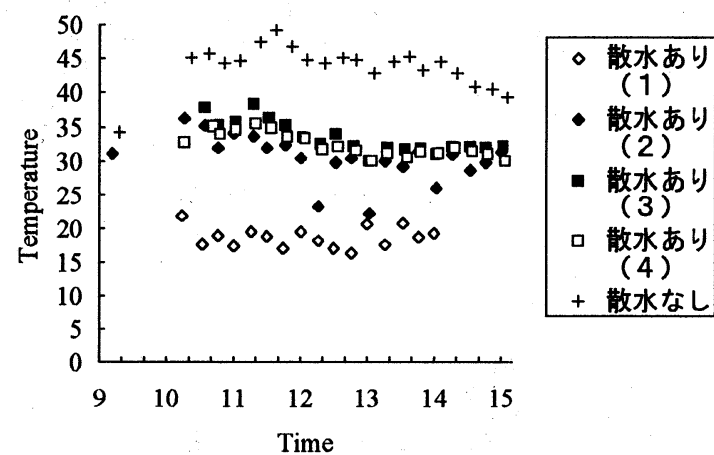

図-11 放射温度計による計測結果

\section{5 熱収支（熱量の配分）}

散水の無い地点では、純放射は地上の空気を加熱する 顕熱と地中への伝導熱に配分される。一方、散水を行う ことにより潜熱への配分が増大寸るのに加え、散水その ものが地面の熱を奪い側溝に流れ落ちる。しかも、今回 は地下水を汲み上げて散水したので水温が約 15 度位と安 定しており、後述するように移流の効果もかなり大き かった。

アスファルト道路面での熱収支式および散水の連続式 は次のように表される。

$$
\begin{aligned}
& R_{n}= \begin{cases}G+H+\ell E+C \rho \frac{d\left(q T_{w}\right)}{d s} \text { (Watering) } & \cdots(1)-a \\
G+H \quad \text { (No watering) } & \cdots(1)-b\end{cases} \\
& \mathrm{R}_{\mathrm{n}}=(1-\alpha) \mathrm{S}+\mathrm{L}-\sigma \mathrm{T}^{4}, \quad \frac{\mathrm{dq}}{\mathrm{ds}}=-\mathrm{E} \quad \cdots(1)-\mathrm{c}
\end{aligned}
$$

ここに、 $\mathrm{q}$ : 単位幅当たりの流量、 $\mathrm{s}$ : 散水の流下方向、 $\mathrm{Tw}$ : 水温で、他の記号は慣例に従うものとする。

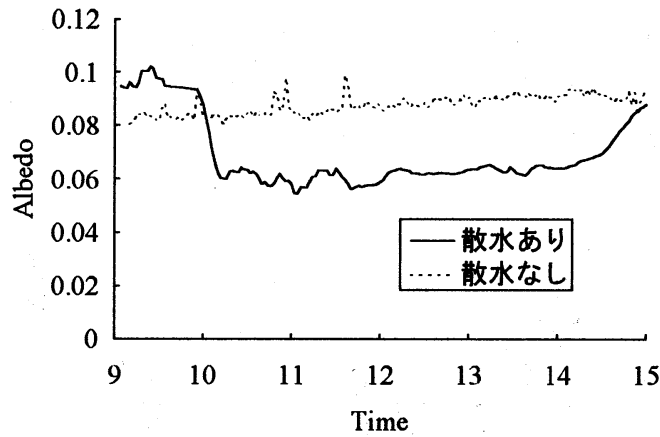

図-10アアルベドの時間変化

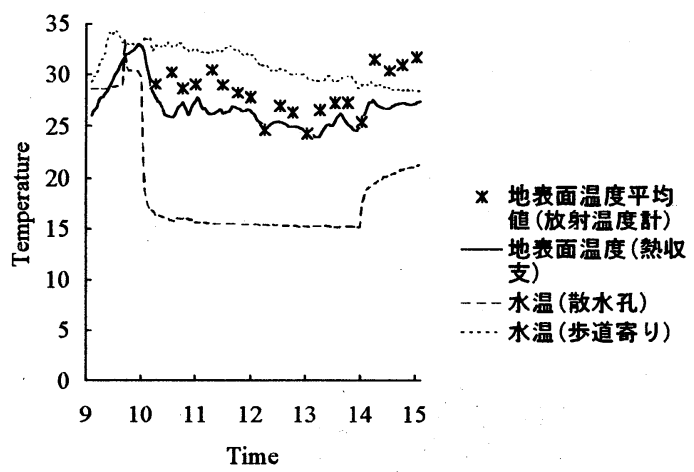

図-12 地表面温度の推定結果 (A地点)

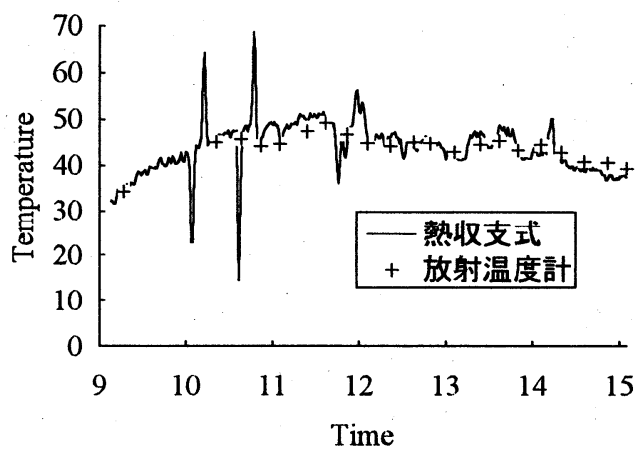

図-13 地表面温度の推定結果 (B地点)

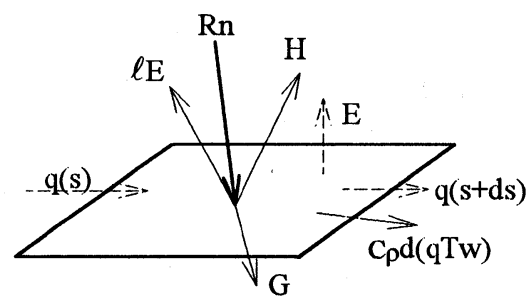

散水の流入する路面での熱収支 
A地点における熱収支は以下のように算定した。式(1)-aでqの変化を無視し、道路中央部と側溝付近での白 金温度計による水温計測結果及び散水孔からの散水量（ほぼ一定して $13.1 \mathrm{~cm} / \mathrm{s} / \mathrm{m}$ )を用いて算定された散水時 間内での熱の移流量は250〜 310W/m²であった。超音波風速計による計測結果は $\mathrm{H}=\mathrm{C}_{\mathrm{p}} \rho \overline{w^{\prime} \theta^{\prime}}$ により顕熱に換算 した。今回の観測では埋設用の厚さ $4 \mathrm{~mm} の$ 熱流計を路面上に敷設しテープで覆ったことから、地中伝導熱 $\mathrm{G} の$ 計測結果はかなり小さな值を記録した。そこで、9 時から10時までは散水を行っていないので式(1)-bに従う ことから $=0$ の条件を満たすようにGの計測結果を補正した。補正にあたっては、熱流計上面の熱収支式、放 射量と Gの計測結果を用いて推定した熱流 計下面の温度、路面温度の計算值、熱流計 の感度定数、熱抵抗を用いた。補正後の $\mathrm{G}$ の值および前述の式(1)-a各項の值の時間 変化を 10 分間の移動平均值で示すと図 -14 のようになる。これによると、散水直後は 急激に路面温度が低下寸ることから地中熱 は負の值に転じ、潜熱量も非常に大きく なっている(図-16)。しかし、時間の経過 とともに潜熱量は徐々に減少していること がわかる。これを裹付けるようにA、B地点 の湿度差も徐々に減少している。なお、 9 時半ごろに Gの值が急激に小さくなり、潜 熱輸送がみられたのは予備散水を数分間 行ったことによると考えられる。

次に、顕熱、潜熱を傾度法による推定值 と比較したところ図-15,16のようになった。 顕熱の計測值では散水開始による急激な顕 熱量の減少は見られず、午後 1 時前後には 顕熱量が負の値を記録しているものの傾度 法を用いた顕熱の推定值に比べると、散水 開始後で数十W/ $\mathrm{m}^{2}$ 大きめになっている。ま た、潜熱の場合は傾度法による推定值と熱 収支から推定した值では特に散水開始直後 に大きな違いが見られる。これらは散水に

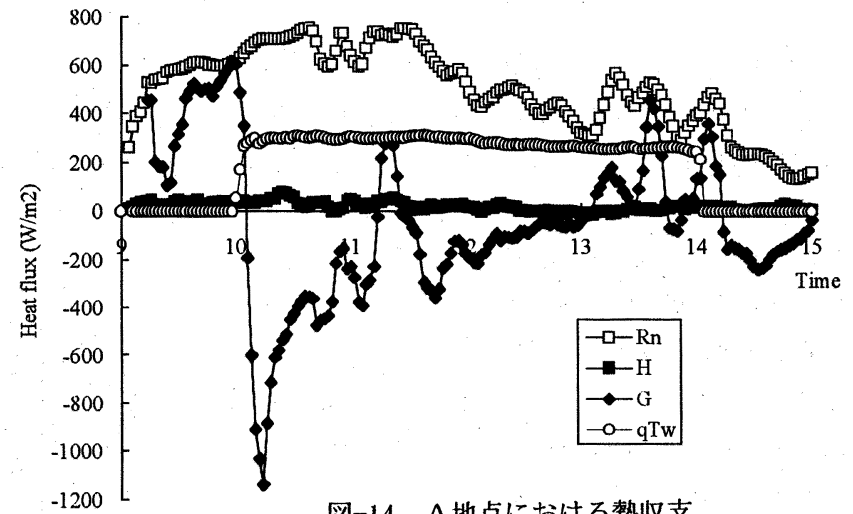

図-14 A地点における熱収支

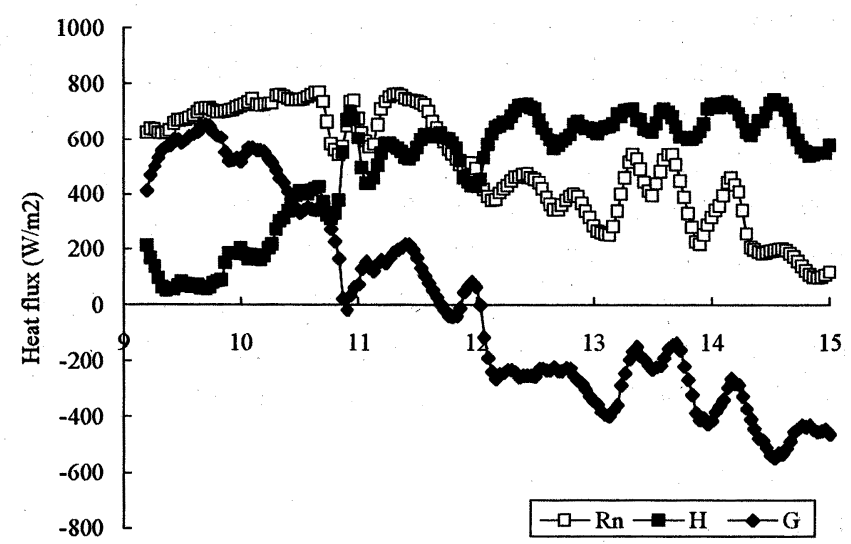

図-17 B 地点における熱収支 より対流が発生したことが原因と考えられる。また、散水開始後は時間の経過とともに潜熱量は徐々に減少し 散水終了後再び増加したのは、側溝へ向かう流れによる移流の影響とみられる。以上から、今回の観測では地 中伝導熱の計測精度に問題が残るが図-14〜16の結果は散水直後を除いては傾向的にも熱量の大きさとしても 実態を表しているものと推定される。

散水の無い $\mathrm{B}$ 地点における熱収支は図-17のような結果となった。A地点同様に地中への伝導熱は補正を

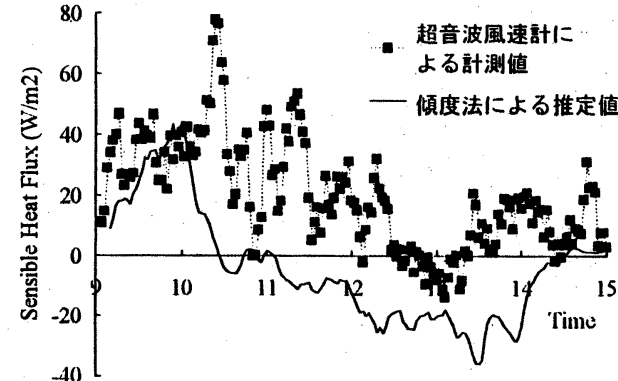

图-15 㩆热の数测值と推定值

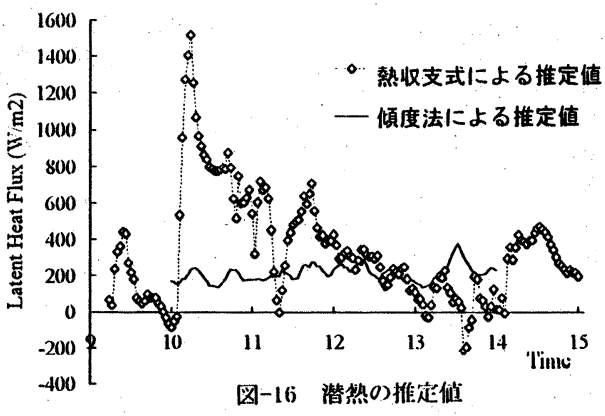

图-16 潜然0)推定储 
行ったものである。この図では純放射量が減少傾向にある12時頃にはすでにGは大気への放熱に転じたため顕 熱が600W/m² 以上大きな值となっているが、 $\mathrm{G}$ 年大気への放熱に転じるのは一般に午後 3 時頃である2)ことか ら Gの補正值の信頼性については改めて確認する必要がある。

A、B両地点を比べると、地中伝導熱及び顕熱は散水開始まではほぼ同様の值となっていたが、散水により大 量の熱が潜熱及び移流分として輸送されたため、急激な放熱が行われ、その後の傾向がかなり両地点で異なっ ている。それにもかかわらず、両地点における気温に期待されるほどの差が生じなかったのはA地点から B 地 点へ向から風が大きく影響しているものと考えられる。

\section{4. 散水による温熱環境の改善効果}

ここでは、計測結果から不快指数と熱負荷量を算定して散水による温熱環境の改善効果を評価する。不快指 数が気温と湿度から判定される室内環境に対する温熱指標であるのに対して、熱負荷量は人体が周辺から受け る正味の熱量であり、気温、湿度、風、放射を考慮 (W/m²)

した屋外における温熱指標といえる。

不快指数（D I）は式(2)により算出した ${ }^{3)}$ 。

$\mathrm{DI}=0.81 \mathrm{~T}+0.01 \mathrm{R}_{\mathrm{h}}(0.99 \mathrm{~T}-14.3)+46.3 \cdots(2)$

ここに、 $\mathrm{T}$ : 気温 $\left({ }^{\circ} \mathrm{C}\right) 、 \mathrm{R}_{\mathrm{h}}$ : 相対湿度 $(\%)$ である。ま

た、人体の熱負荷量 $(\mathrm{F})$ は式(3)で定義される。

$\mathrm{F}=\mathrm{R}+\mathrm{M}-\mathrm{r}-\mathrm{C}-\mathrm{E} \cdots(3)$

ここに、 $\mathrm{R}$ : 放射による受熱量、 $\mathrm{M}$ ：人体の代謝量、

$\mathrm{r}$ : 人体から大気への赤外放射、 $\mathrm{C}$ : 対流による放熱

量、 $\mathrm{E}$ : 蒸発による放熱量である。各項の推定式およ

び推定方法は神田・土屋4)に従い、人体の体表面温度

は一定値と仮定した。

図-18は不快指数と熱負荷量の算定結果で、散水の 有無による不快指数の違いは平均的にはほとんどみ

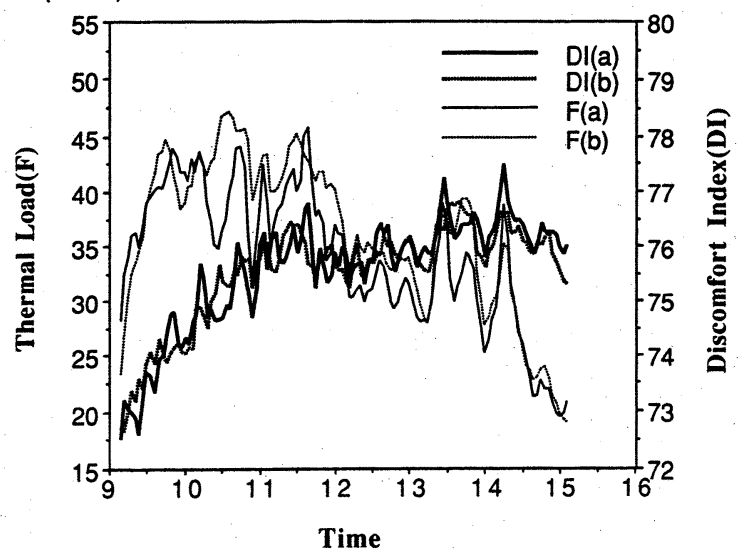

図-18 温熱指標值の時間変化

られないが、熱負荷量では散水により $10 \mathrm{~W} / \mathrm{m}^{2}$ 程度抑制されている。この量に対して仮に裸体からの顕熱量の増 加(体温の上昇)のみで対処したとすると体温は約1.5度上昇することになる。このことから散水の効果は室内 の熱環境を改善するまでは及ばないが路面と建築物で覆われた空間では熱負荷量の減少につながり非常に有効 であるといえる。

\section{5. おわりに}

都市内散水の現地実験により、1)わずかな距離しか隔てられていなくても散水の有無により気温と湿度の明 確な差が生じる、2）地下水による熱の移流の効果が大きい分、湿度の上昇を抑制する、3)道路散水が路面温度 の上昇を抑えることにより熱環境の緩和に有効に機能すること、などが明らかとなった。

消雪用パイプの既設地域では酷暑対策として散水の導入が比較的容易であるとともに、建設、維持管理費用 いかんでは新規に導入することも可能であることから、各都市の熱環境の実態、散水による道路交通への支障、 歩行者への影響、散水用水源の確保などについて十分に考慮した上で散水が実施されることが望ましい。

最後に、現地観測を行うにあたり協力を得た建設省信濃川工事事務所、長岡市土木部、観測を手伝って頂い た土木研究所都市河川研究室の今村氏、小西氏、山梨大学 4 年の土屋氏、立川氏に深く感謝いたします。なお、 本研究の一部は文部省科学研究費奨励研究 (A)（番号05750483）の援助を受けたことを記し、謝意を表します。

参考文献：1)神田、安部、日野：ヒートアイランド防止策としての散水効果の検討、水文水資源学会1993研究発 表会要旨集、2) 浅枝、藤野: 舖装面の熱収支と蓄熱特性について、水文·水資源学会誌、Vol. 5, No. 4, 1992.、3) 理科年表 (1992)、266p 、4) 神田、土屋: 微気象観測に基づく人間熱収支解析の試み、第38回水理講演会(投稿中) 